\title{
Suggested improvements of the general cardiology ward round - An opinion paper
}

\author{
Christian Bjurman*1, Tord Juhlin ${ }^{2}$, Martin J. Holzmann ${ }^{3,4}$ \\ ${ }^{1}$ Department of Internal Medicine, Halland's Hospital, Sweden \\ ${ }^{2}$ Division of Arrythmia, Heart and Lung Clinic, Skåne University Hospital, Malmö, Sweden \\ ${ }^{3}$ Functional Area of Emergency Medicine, Karolinska University Hospital, Huddinge, Stockholm, Sweden \\ ${ }^{4}$ Department of Internal Medicine, Solna, Karolinska Institutet, Stockholm, Sweden
}

Received: October 19, 2017

DOI: $10.5430 /$ jha.v7n1p18
Accepted: January 17, $2018 \quad$ Online Published: January 20, 2018

URL: https://doi.org/10.5430/jha.v7n1p18

\begin{abstract}
General cardiology ward rounds have become more complicated owing to higher production demands combined with continued efforts to improve patient safety. The traditional ward round is now outdated and needs changing to better suit the current environment. After describing the traditional ward round and some alternative rounding systems tested in Sweden, we suggest some simple measures to improve efficiency, patient-centeredness, and patient safety. This article is addressed mainly to health care leaders and physicians in a position to make changes to rounding structures and hospital organization. We hope that this analysis will prompt a debate that will lead to eventual improvements in health care and work satisfaction.
\end{abstract}

Key Words: Ward round, Patient-centered care, Efficiency, Communication, Time allocation, Checklist, Work distribution

\section{INTRODUCTION}

There has been a gradual decrease in the number of hospital beds in Sweden ${ }^{[1,2]}$ and a resultant requirement for more efficient patient care, including a shorter duration of in-hospital care. This must be achieved without compromising patient safety. ${ }^{[3]}$ Higher workloads have contributed to difficulties in recruiting and retaining nurses in Swedish public health care. ${ }^{[4]}$ To break this ongoing vicious circle, measures are needed to improve working conditions, especially for nurses.

In this opinion paper, we focus on the traditional ward round, contrast it with alternative rounding models tested in Sweden, and comment on the potential strengths and shortcomings of these alternatives. Finally we suggest a novel holistic approach to rounding in general cardiology wards that includes a time allocation model and checklists. This approach is guided by our own experiences and previous research findings ${ }^{[5,6]}$ (including lessons from aircraft management ${ }^{[7]}$ ) and is intended to improve patient-centeredness (see Table 1) and patient safety, and release more time for nurses. Focusing on cardiac care rounding, our main objective is to start a debate that will hopefully lead to improvements and further research in the field.

Table 1. Main components of patient-centeredness

\begin{tabular}{l}
\hline Components of patient-centeredness \\
\hline - Autonomy \\
- Comfort \\
- Confidentiality \\
- Informed decision making \\
\hline
\end{tabular}

*Correspondence: Christian Bjurman; Email: christian.bjurman@ regionhalland.se; Address: Halland’s Hospital Varberg, Träslövsvägen 68,43237 Varberg, Sweden. 


\subsection{Importance of patient-centeredness}

Patient-centered care (see Table 1) emphasizes informed decision making in order to influence treatment choice and improve outcomes and quality of care. ${ }^{[8]}$

However, patients do not always receive sufficient information from physicians to enable them to make informed decisions. For example, according to one study, only $3 \%$ of patients with stable angina received sufficient information to make an informed decision about undergoing coronary angiography and possible subsequent percutaneous coronary intervention. ${ }^{[9]}$

Therefore, one important aim in planning a new system of ward rounding must be increased patient-centeredness (see Table 1). ${ }^{[10]}$ The system should facilitate patient involvement in decisions about treatment and care, improve communication with patients about upcoming treatments and preliminary discharge dates ${ }^{[11]}$ and promote confidentiality.

\subsection{Measures to improve patient safety}

Any plans for new ward rounding systems should seek to increase patient safety. Patient safety does not depend solely on good medical knowledge. Crew Resource Management, a model originating from the aircraft industry, advocates the use of different systems to reduce errors using standardization and checklists. ${ }^{[12]}$ Checklists can also reduce complications and facilitate early discharge of patients. ${ }^{[13]}$

Both written and oral communication of important patient information should follow an established model of communication, such as the Situation, Background, Assessment, and Recommendation (SBAR) model (see Table 2). ${ }^{[14]}$ The SBAR ensures structured communication and can improve outcomes and nurse-physician communication. ${ }^{[14]}$ Research in anesthesiology shows that this model can lead to improvements in the safety climate and can decrease incident reports owing to communication errors. ${ }^{[15]}$ The SBAR has been used to improve communication with colleagues, patients, and patients' next of kin. ${ }^{[16]}$

\subsection{Existing rounding models}

A traditional Swedish round usually lasts a couple of hours and involves a discussion between nurses and physicians. ${ }^{[17]}$ Decisions are mostly based on the information available in medical records. After the round, patients are told about the care decisions. There are several alternative rounding models,${ }^{[18-26]}$ which aim to increase efficiency and/or patientcenteredness.

Table 2. SBAR model

\begin{tabular}{lll}
\hline Abbreviation & Meaning & Description \\
\hline $\mathrm{S}$ & Situation & A brief description of the problem \\
$\mathrm{B}$ & Background & Relevant information related to the situation \\
$\mathrm{A}$ & Assessment & Findings and thoughts \\
$\mathrm{R}$ & Recommendation & Recommended action \\
\hline
\end{tabular}

In "need-governed rounding" ("behovsstyrd rond" in Swedish), ${ }^{[18-20]}$ patient needs guide care and are continuously reassessed. The physician regularly ranks the patients' needs and visits the most critically ill patients first. ${ }^{[18]}$ Newly arrived or deteriorating patients are rounded in the morning, other patients are rounded throughout the day, and patients who have received prolonged hospital care or who are ready for discharge are visited less frequently. ${ }^{[18]}$

In the "bedside rounds" used in an intensive care unit in Stockholm, the patient is directly rounded in the patient room. ${ }^{[21]}$ Physicians and other health care professionals stand together at the patient's bedside, conducting examinations and updating themselves about the patient's condition; this produces a context of continuous care. ${ }^{[21]}$

In Kungälv, ${ }^{[23-25]}$ the "second round" ("andra ronden" in Swedish) model is used. Patients are fetched one at a time into a room in which the whole patient team is sitting. In this type of rounding, the whole care team hears what is said and participates in the patient's whole care process. ${ }^{[23]}$

Sometimes the contribution of allied health workers (e.g., dieticians, physiotherapists, and social workers) is paramount to patient care. A multidisciplinary team round is an opportunity to jointly plan and evaluate the patient's treatment and transfer of care. ${ }^{[26]}$ The multidisciplinary round is patientcentered and based on the needs of the patient and their carers. ${ }^{[26]}$

At the cardiac care unit in Jönköping, ${ }^{[27] ~ " s i m p l e " ~ p a t i e n t s ~}$ are discharged before the actual round. In Varberg, a complementary pre-round is conducted at a white board after the clinic's regular morning meeting (at around 9.00 a.m.). All admitted patients in the ward are discussed briefly at the pre-round. Physicians subsequently visit all patients and then attend a sit-down round with the nurse. 


\subsection{Comparisons between different rounding systems}

Traditional ward rounding, in which nurses and physicians meet in a room ${ }^{[17]}$ and then go round to meet the patients and inform them about care decisions, do not promote patientcenteredness.

Need-governed rounding always leads to prioritization of the sickest patients; however, there is a risk that patients will be discharged early, be down-prioritized, or have to remain in the ward longer than necessary.

The sole use of bedside rounds in the patient rooms prevents physicians and other health care professionals from discussing the patient's condition and treatment calmly and in privacy, without the patient present. In complex cases, several specialists may need to be involved and they may need time to consider and produce a balanced treatment plan.

To increase confidentiality and patient co-determination, some hospitals have created "patient-centered rounds". ${ }^{[23-25]}$

The "second round" model, in which patients are individually fetched into a room to discuss their care with the health team, increases patient-centeredness, but has the following potential weaknesses:

(1) The whole ward workforce is occupied, often in a narrow room, for sometimes 2-3 hours.

(2) This model is not suitable for patients with mobility problems or patients with reduced cognition or consciousness.

(3) The admittance of emergency patients in the morning may disrupt planned sessions.

(4) It is difficult for team members to express different opinions in front of the patient before consensus has been reached.

(5) If patients see physicians reading through medical guidelines to refresh their memory, they might develop doubts about the physicians' knowledge.

(6) If a series of patients are seen in the same room, this may spread infections and breach confidentiality.

(7) The allocated rounding time might be insufficient to inform the patient about possible treatment options, allow them to consider each alternative, and enable them to make a decision about treatment.

(8) Physicians may lose control over a ward if there are several emergencies and a high patient turnover.

(9) Patients might be promised a discharge date or a treatment plan that must be changed if new examination results arrive later in the day. In an emergency ward, many patients may have to be fetched to the room more than once daily. This suggests that it is sometimes better to wait and talk to patients when all important investigations are finished or have been summarized.

(10) The increased time demands and involvement of the whole workforce in this model means that staffing may have to be increased to maintain acceptable levels of patient safety.

(11) Should nurses, who are experts on nursing care, be forced to listen to medical discussions that keep them from their ordinary tasks?

(12) How do patients feel about being observed by the whole workforce? Many patients prefer to have time alone with their responsible nurse or physician.

A comparison of findings from the Swedish national patient questionnaires from 2010 and 2012 showed no important differences in patient experiences of care before and after the implementation of this model. ${ }^{[23]}$ The Department of Internal Medicine in Eksjö has implemented a similar organizational change, and staff have reported that this method of rounding takes more time. ${ }^{[28]}$

Multidisciplinary ward rounds seem to be most beneficial for complex patients that need multiple interventions from different health care professionals, like trauma, ${ }^{[29]}$ stroke, ${ }^{[30]}$ or cancer ${ }^{[31]}$ patients. However, multidisciplinary ward rounds may be more time consuming for patients with an isolated problem or symptom, such as chest pain.

A rounding model like the Jönköping one, in which "simple" patients are discharged before the ordinary ward round, consumes important preparatory time before the ordinary ward round starts and prevents residents from gaining a complete overview of the ward. The arrhythmia ward in Lund, Sweden, conducts many repetitive ablation procedures and uses a similar model. This involves early discharge of patients who have undergone standard procedures and appears to work quite well for this type of patient. Table 3 compares different rounding models.

\section{OUR SUGGESTIONS FOR DEVELOPMENT OF THE MEDICAL WARD SYSTEM}

Our proposed rounding system features seven dimensions (see Table 4). These were identified from the preceding literature review and from author experiences.

\subsection{Time allocation system}

Many nurses today do not have enough time to carry out basic nursing care measures. ${ }^{[32]}$ We therefore suggest a novel time allocation system (see Figure 1), one objective of which is to release more time for nurses by not requiring them to attend extended rounds with physicians. This extra time could be used to provide patients with more nursing care. 
Table 3. Comparison of different rounding systems

\begin{tabular}{|c|c|c|c|}
\hline Rounding system & Pros & Cons & Opinions \\
\hline Traditional ward round & Well-established & Less patient-centeredness & $\begin{array}{l}\text { "It is easy for junior physicians to } \\
\text { move between wards without } \\
\text { having to learn a new system" } \\
\text { "Flexible" }\end{array}$ \\
\hline Need-governed rounding & $\begin{array}{l}\text { Leads to prioritization of the } \\
\text { sickest patients }\end{array}$ & $\begin{array}{l}\text { Patients that could be discharged } \\
\text { early are down-prioritized }\end{array}$ & $\begin{array}{l}\text { "One might lose an overview of } \\
\text { the ward" }\end{array}$ \\
\hline Bedside rounds & $\begin{array}{l}\text { Increases patient } \\
\text { involvement } \\
\text { Increases teamwork }\end{array}$ & $\begin{array}{l}\text { Difficult to maintain } \\
\text { confidentiality in rooms } \\
\text { containing more than one patient }\end{array}$ & $\begin{array}{l}\text { "Not all patients want to hear the } \\
\text { team members discussing their } \\
\text { work-up and treatment" }\end{array}$ \\
\hline The second round & $\begin{array}{l}\text { Increases confidentiality, } \\
\text { teamwork, and } \\
\text { patient-centeredness }\end{array}$ & $\begin{array}{l}\text { Not all patients want to be } \\
\text { surrounded by the whole } \\
\text { workforce } \\
\text { It is difficult for the team to } \\
\text { express different opinions in } \\
\text { front of the patient }\end{array}$ & $\begin{array}{l}\text { "The system takes more time than } \\
\text { traditional ward rounding" }\end{array}$ \\
\hline $\begin{array}{l}\text { Multidisciplinary team } \\
\text { ward rounding }\end{array}$ & $\begin{array}{l}\text { Care goals and plans become } \\
\text { clear to everyone }\end{array}$ & $\begin{array}{l}\text { Might be superfluous and time } \\
\text { consuming for treatment of } \\
\text { standard patients }\end{array}$ & $\begin{array}{l}\text { "Not all patients need } \\
\text { multidisciplinary involvement" }\end{array}$ \\
\hline $\begin{array}{l}\text { Discharge of "simple" } \\
\text { patients before the actual } \\
\text { ward round }\end{array}$ & $\begin{array}{l}\text { Patients that are regarded as } \\
\text { fit for discharge do not need } \\
\text { to wait until the afternoon } \\
\text { Hospital beds are freed in the } \\
\text { morning for new patients }\end{array}$ & $\begin{array}{l}\text { Consumes important preparatory } \\
\text { time before the ordinary ward } \\
\text { round, particularly for junior } \\
\text { physicians }\end{array}$ & $\begin{array}{l}\text { "Residents will often not have a } \\
\text { full overview of the ward" }\end{array}$ \\
\hline $\begin{array}{l}\text { Complementary } \\
\text { pre-rounds }\end{array}$ & $\begin{array}{l}\text { Can be used for efficient work } \\
\text { allocation among team } \\
\text { members }\end{array}$ & $\begin{array}{l}\text { Often becomes a "light" ward } \\
\text { round, as it is not always easy to } \\
\text { separate it from the ordinary } \\
\text { round }\end{array}$ & $\begin{array}{l}\text { "The pre-round is helpful to } \\
\text { prioritize between tasks and get } \\
\text { introduced to the team early in the } \\
\text { morning" }\end{array}$ \\
\hline
\end{tabular}

Table 4. Our suggested medical ward rounding system

\begin{tabular}{|c|c|c|c|}
\hline Dimension & Advantages for physicians & Advantages for nurses & Advantages for patients \\
\hline Time allocation system & $\begin{array}{l}\text { Fresh lab data and National Early } \\
\text { Warning Score parameters }{ }^{[25]} \text { for all } \\
\text { patients early in the morning, which } \\
\text { is important for treatment planning }\end{array}$ & Frees up time & $\begin{array}{l}\text { Increases patient safety } \\
\text { and hopefully allows more } \\
\text { time with nurses }\end{array}$ \\
\hline $\begin{array}{l}\text { Checklists for blood sampling and } \\
\text { vital parameters for standard } \\
\text { patients on the cardiac ward }\end{array}$ & Frees up time & $\begin{array}{l}\text { Frees up time and } \\
\text { probably increases } \\
\text { work satisfaction }\end{array}$ & $\begin{array}{l}\text { Increases patient safety } \\
\text { and probably shortens } \\
\text { length of stay }\end{array}$ \\
\hline $\begin{array}{l}\text { Complicated patients discussed in } \\
\text { conference form }\end{array}$ & Increases quality of care & & $\begin{array}{l}\text { Increases patient safety } \\
\text { and probably shortens } \\
\text { length of stay }\end{array}$ \\
\hline Communication in the hospital & Increases work satisfaction & $\begin{array}{l}\text { Increases work } \\
\text { satisfaction }\end{array}$ & Increases patient safety \\
\hline $\begin{array}{l}\text { Measures to increase } \\
\text { patient-centeredness }\end{array}$ & & & $\begin{array}{l}\text { Increases patient safety } \\
\text { and satisfaction with care }\end{array}$ \\
\hline $\begin{array}{l}\text { Measures to increase work } \\
\text { satisfaction for nurses }\end{array}$ & & $\begin{array}{l}\text { Increases work } \\
\text { satisfaction }\end{array}$ & \\
\hline $\begin{array}{l}\text { Optimization of the architecture of } \\
\text { the ward }\end{array}$ & $\begin{array}{l}\text { Increases work satisfaction and } \\
\text { reduces stress }\end{array}$ & $\begin{array}{l}\text { Increases work } \\
\text { satisfaction and reduces } \\
\text { stress }\end{array}$ & \\
\hline
\end{tabular}




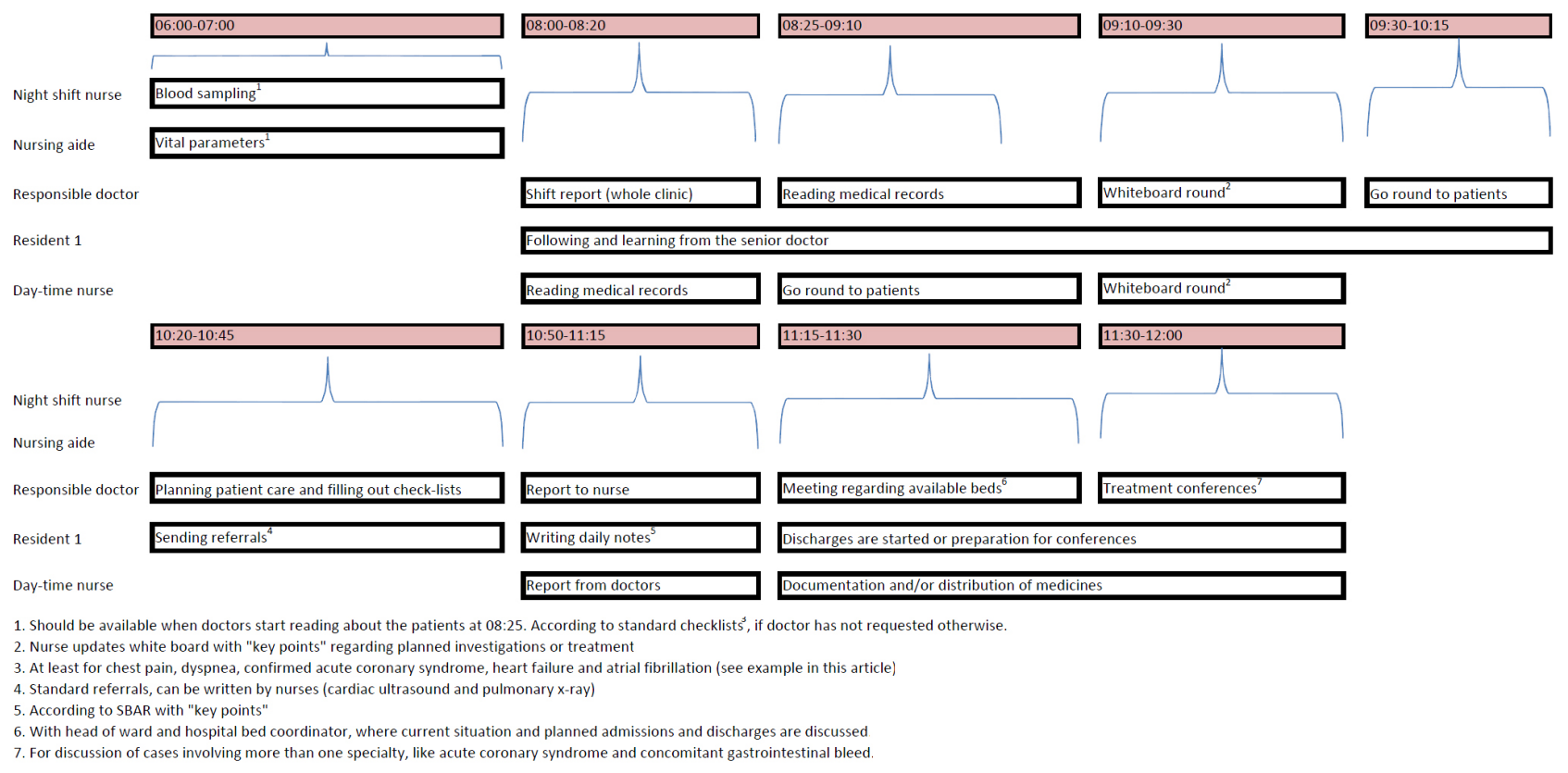

Figure 1. Time allocation model

The time allocation model also ensures that physicians receive fresh laboratory data and National Early Warning Score parameters ${ }^{[33]}$ for all patients on the ward as early as possible, so that this data can inform their reading of patient medical records. The model offers a clear structure for morning work, but does not regulate afternoon work. The latter work could be more flexible and focus on the following tasks:

(1) Talks with relatives

(2) Cardiac conferences

(3) Emergency admissions, discharges, and other unexpected situations

(4) Bedside education for younger colleagues

(5) Signing of electronic patient charts

However, we suggest that need-governed rounding should be used for sicker patients arriving at the ward in the afternoon, to avoid delaying specialist assessment to the following day, and that critically ill patients are handled with complementary bedside rounds.

Our care model is a development and synthesis of existing rounding models. Compared with the traditional care organization and rounding system in Sweden, our proposed system has several potential advantages:

(1) Nurses' time is not taken up with daily meetings in the physician's office (which can sometimes last for more than 2 hours) during the morning round.

(2) The responsible physician does not make any crucial care decisions before having met the patient and created his/her own updated "image" of the patient's condition, or without having heard the patient's own wishes. This is important, as the physician's assessment is not solely based on vital parameters and laboratory results. The model therefore leads to increased patient-centeredness.

\subsection{Checklists for blood sampling and vital parameters for standard patients on the cardiac ward}

We suggest that symptom- and/or diagnosis-specific checklists are used for the following common patient groups:

(1) Unspecified chest pain (Figure 2 shows an example)

(2) Acute coronary syndrome

(3) Unspecified dyspnea

(4) Heart failure

(5) Atrial fibrillation

A general checklist has already been developed to ensure that all aspects of care on a team's general internal medicine ward round have been adequately addressed. ${ }^{[34]}$

\subsection{Complicated patients discussed in conference form}

For patients who deviate from the "standard flow", team conferences should be arranged as necessary, in which other specialists are invited to contribute their expert knowledge. For example, such conferences may be relevant for patients with myocardial infarction and concomitant gastrointestinal bleed or pronounced renal dysfunction.

\subsection{Communication in the hospital}

Important communications, in both oral and written daily note form, should follow an established and evidence-based communication model, such as the SBAR. ${ }^{[14-16]}$ 


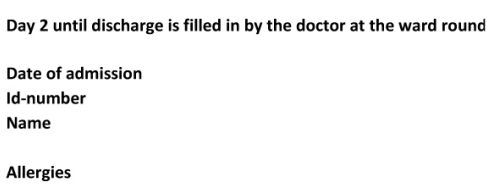

Figure 2. Checklist for patients with unspecified chest pain ${ }^{1}$

\subsection{Simple measures to increase patient-centeredness}

If possible, patients should be asked about their attitude to the care and treatment offered; ${ }^{[35]}$ however, not all patients

wish to participate in shared decision making. ${ }^{[36]}$

Patients should also be asked to prepare questions for the medical round and be informed that they are allowed to par- 
ticipate in decisions about their care and treatment. To enable patients to contribute meaningfully to decision making, they should receive short letters (which could be standardized) containing simplified written information about their disease.

Nurses should also inform patients which physician is responsible for their care and ask patients more directly what they want and expect from their hospital stay. However, it is wrong to assume that all patients want or can be involved in their care. When appropriate, relatives should be invited to visit the hospital to talk to the responsible physician or nurse.

\subsection{Measures to increase work satisfaction for nurses}

Increased work satisfaction can probably be achieved through a better, clearer work distribution, using standardization of care for common patient groups such as unspecified chest pain. It is likely that many nurses experience confusion when different physicians handle the same condition in disparate ways. Standardization of care for common reasons for admission decreases the need for communication within the team, thus saving time and reducing the likelihood of loss of information.

Nurses on wards that treat patients with cardiac disease should have basic knowledge about the care of confirmed ${ }^{[37]}$ or suspected myocardial infarction ${ }^{[38]}$ and heart failure, ${ }^{[39]}$ although this is not always the case owing to high degrees of staff turnover. Nurses should also be able to evaluate ambulance electrocardiograms (ECGs) and ward ECGs to determine if an ECG shows ventricular rhythm or ischemia. On suspicion of ECG pathology, a physician should be contacted for further assessment. This arrangement filters out the large number of normal ECGs, which take time from physicians' other tasks. Furthermore, the ability to conduct a basic interpretation of rhythm and heart frequency on telemetry alarms, and document it in the medical record, is useful. A special license procedure could be implemented for these skills using web-based teaching and a subsequent examination.

\subsection{The architecture of the ward}

Physicians' offices should be located close to the nurses' offices to promote continuous dialogue throughout the day and avoid the need to telephone or search for colleagues.

\section{Conclusions}

In summary, our suggested ward system is likely to increase work satisfaction, efficiency, and patient safety. The model could also increase patient-centeredness and provide valuable time to talk to relatives and engage in education, something that many physicians today do not have enough time for. ${ }^{[40]}$ Many of the ideas discussed here could be applied to other types of wards, particularly wards with a high proportion of standard patients admitted for short observation periods.

\section{ACKNOWLEDGements}

We thank Diane Williams, PhD, from Edanz Group (www . ed anzediting. com/ac) for editing a draft of this manuscript.

\section{CONFLicts OF InTEREST Disclosure}

The authors declare they have no conflicts of interest.

\section{REFERENCES}

[1] Lövtrup M. Rekordstor minskning av vårdplatserna [Record in reduction of hospital beds]. Läkartidningen; 2017 Aug 14. Available from: http://www.lakartidningen.se/Aktuellt/Nyheter/2017/ 06/Rekordstor-minskning-av-vardplatserna-2016/

[2] Borgström A Sverige har lägst antal vårdplatser i Europa [Sweden has the lowest number of hospital beds per capita in Europe]. Läkartidningen; 2017 Aug 14. Available from: http://www.lakartidning en.se/OldWebArticlePdf/6/6069/LKT0706s396_397.pdf

[3] Carayon P, Gurses AP. Chapter 30 Nursing Workload and Patient Safety-A Human Factors Engineering Perspective. Patient Safety and Quality: An Evidence-Based Handbook for Nurses. 2018 Jan 15. Available from: https://www.ncbi.nlm.nih.gov/books/N BK2657/

[4] Dåliga villkor bakom sjuksköterskeflykt [Poor working conditions behind nurses leaving their work places]. Dagens Medicin. 2017 Aug 14. Available from: https://www.dagensmedicin.se/artiklar/2017/05/05/d aliga-villkor-bakom-sjukskoterskeflykt/

[5] Aspesi AV, Kauffmann GE, Davis AM, et al. IBCD: Development and testing of a checklist to improve quality of care for hospitalized general medical patients. Jt Comm J Qual Patient Saf. 2013 Apr; 39(4): 147-56. https ://doi .org/10.1016/S1553-7250(13)3 9021-7

[6] Hess EP, Hollander JE, Schaffer JT, et al. Shared decision making in patients with low risk chest pain: Prospective randomized pragmatic trial. BMJ. 2016; 355: i6165. PMid: 27919865. https : //doi .org/10.1136/bmj.i6165

[7] Swartz MK. What health care is learning from the aviation industry. J Pediatr Health Care. 2015; 29(1): 1-2. PMid: 25497134. https://doi.org/10.1016/j.pedhc. 2014.09.005

[8] Ravishankar Jayadevappa SC. Patient centered care - a conceptual model and review of the state of the art. The Open Health Services and Policy Journal. 2011; 4(1): 15-25. https://doi .org/10. 217 4/1874924001104010015

[9] Rothberg MB, Sivalingam SK, Kleppel R, et al. Informed decision making for percutaneous coronary intervention for stable coronary disease. JAMA Intern Med. 2015; 175(7): 1199-206. PMid: 25984988. https://doi.org/10.1001/jamainternmed. 2015 .1657

[10] Goldfarb M. A cardiology fellow's guide to patient-centered care. JACC. 2017; 69(23): 2871-4. PMid: 28595705. https ://doi .or 
g/10.1016/j.jacc. 2017.05 .001

[11] Wolfel T, Beltermann E, Lottspeich C, et al. Medical ward round competence in internal medicine - an interview study towards an interprofessional development of an Entrustable Professional Activity (EPA). BMC Med Educ. 2016; 16: 174. PMid: 27401103. https://doi.org/10.1186/s12909-016-0697-y

[12] O'Daniel M, Rosenstein AH. Chapter 33. Professional communication and team collaboration. In: Hughes RG, editor. Patient safety and quality: An evidence-based handbook for nurses. Advances in patient safety. Rockville (MD): Agency for Healthcare Research and Quality U.S. Department of Health and Human Services; 2008. 6 p.

[13] Garg P. Cardiology a ward rounds: rationale of using a checklist. Clin Med (Lond). 2011; 11(3): 299. https ://doi .org/10.7861/ clinmedicine.11-3-299

[14] De Meester K, Verspuy M, Monsieurs KG, et al. SBAR improves nurse-physician communication and reduces unexpected death: a pre and post intervention study. Resuscitation. 2013; 84(9): 11926. PMid: 23537699. https://doi.org/10.1016/j.resuscit ation.2013.03.016

[15] Randmaa M, Martensson G, Leo Swenne C, et al. SBAR improves communication and safety climate and decreases incident reports due to communication errors in an anaesthetic clinic: a prospective intervention study. BMJ Open. 2014; 4(1): e004268. PMid: 24448849. https ://doi.org/10.1136/bmjopen-2013-004268

[16] Strukturerad kommunikation minskar riskerna i vården, SBAR [Structured communication reduces risks in health care, SBAR]. Sveriges Kommuner och Landsting. 2017. Available from: https://skl.se/halsasjukvard/patientsakerhet/sbarf orkommunikation.748.html

[17] Wolf A, Ekman I, Dellenborg L. Everyday practices at the medical ward: a 16-month ethnographic field study. BMC Health Serv Res. 2012; 12: 184. PMid: 22748059. https ://doi.org/10.1186/14 72-6963-12-184

[18] Bättre flöde i vården - Vård på rätt nivå till, genom och från Norrlands universitets sjukhus. Västerbottens läns landsting [Better care flows - Care on the right level to, through and from Norrland University Hospital]. Cited 2018 Jan 15. Available from: http: http://memeologen.se/wp-content/uploads/2015/09/R apport-V\%C3\%A5rd-p\%C3\%A5-r\%C3\%A4tt-niv\%C3\%A5-Nus_2 015_II.pdf

[19] Avdelning 30 HIA [Ward 30, Coronary Care Unit]. Capio S:t Görans Sjukhus. Cited 2018 Jan 15. Available from: https://capiostgoran.se/avdelningar-och-mottagnin gar/avdelningar/avdelning-30/

[20] Lean \& flödesorientering [Lean and flow orientation]. Capio S:t Görans Sjukhus. Cited 2018 Jan 15. Available from: https : //ca piostgoran.se/om-oss/lean--flodesorientering/

[21] Bedside-rond ger bättre teamkänsla kring patienten [Bedside rounds result in better team feeling around the patient]. Capio S:t Görans Sjukhus. Cited 2017 Aug 23. Available from: https://capiostgoran.se/om-oss/nyheter/for-dig-som -vill-veta-mer/2017/bedside-rond-ger-battre-teamk ansla-kring-patienten/

[22] Jessika Fritzon J, Gundberg S. Lean Production i sjukvården. Faktorer som påverkar patienttillfredsställelsen och sjuksköterskans arbete [Lean production in hospital care. Factors influencing patient satisfaction and nurses' work]. Sahlgrenska Academy. Cited 2017 Aug 23. Available from: https : //gupea.ub.gu.se/bitstream /2077/29314/1/gupea_2077_29314_1.pdf

[23] Lövtrup M. Här är patienten del i teamet [Here, the patient is part of the team]. Läkartidningen. Cited 14 Aug 2017. Avail- able from: http://www.lakartidningen.se/Aktuellt/Nyh eter/2014/06/Har-ar-patienten-del-i-teamet/

[24] Aijmer L. Narrativ medicin på Kungälvs sjukhus [Narrative medicine at Kungälv hospital]. University of Gothenburg. Cited 2017 Aug 23. Available from: http://sahlgrenska.gu.se/forskning/aktuellt/nyh et/? language Id=100000\&content Id=1382681\&disableRe direct=true\&returnUrl=http $\% 3 \mathrm{~A} \% 2 \mathrm{~F} \% 2 \mathrm{Fsahlgrenska} \cdot \mathrm{gu}$ .se $\% 2$ Fenglish $\% 2$ Fresearch $\% 2$ Fnews-article $\% 2 F \% 2$ Fnarr ative-medicine-at-kungalv-hospital-.cid1382681

[25] Bfajglaeln K. Physician experiences of patient-centered and teambased ward rounding - an interview based case-study. Journal of Hospital Administration. 2014; 3(6): 127-42.

[26] Multidisciplinary Ward Rounds. NSW Department of Health. Cited 2017 Dec 8. Available from: http: //www.health.nsw.gov.au/nursing/projects/Publi cations/multidiciplinary-ward-rou.pdf

[27] Rondsystem Hjärtvårdsavdelningen Ryhov [Rounding system at Cardiology Ward Ryhov]. Region Jönköpings län. Cited 2018 Jan 15. Available from: http://plus.rjl.se/info_files/infosida3 4857/c1_rubensson_rommedahl.pdf

[28] Jakobsson M. Nytt rondsystem på medicinkliniken [New rounding system at the department of internal medicine]. Vimmerby tidning. Cited 2018 Jan 15. Available from: http: //www.vimmerbytidning.se/nyheter/eksjo-mariannelun d/nytt-rondsystem-pa-medicinkliniken-20120908/

[29] Dutton RP, Cooper C, Jones A, et al. Daily multidisciplinary rounds shorten length of stay for trauma patients. J Trauma. 2003; 55(5): 913-9. PMid: 14608165. https://doi.org/10.1097/01.TA.00 00093395.34097 .56

[30] Stroke Rehabilitation Ward. Salford Royal NHS Foundation Trust. Cited 2017 Dec 8. Available from: http://www.srft.nhs.uk/about-us/depts/stroke/p ts/stroke-rehabilitation-ward/

[31] Whale Z. The participation of hospital nurses in the multidisciplinary ward round on a cancer-therapy ward. Journal of Clinical Nursing. 1993; 2(3): 155-63. https ://doi .org/10.1111/j.1365-2702. 1993.tb00155.x

[32] West E, Barron DN, Reeves R. Overcoming the barriers to patientcentred care: time, tools and training. J Clin Nurs. 2005; 14(4): 435-43. PMid: 15807750. https://doi.org/10.1111/j.1365 $-2702.2004 .01091 . x$

[33] Smith GB, Prytherch DR, Meredith P, et al. The ability of the National Early Warning Score (NEWS) to discriminate patients at risk of early cardiac arrest, unanticipated intensive care unit admission, and death. Resuscitation. 2013; 84(4): 465-70. PMid: 23295778. https : //doi.org/10.1016/j.resuscitation.2012.12.016

[34] Herring R, Desai T, Caldwell G. Quality and safety at the point of care: how long should a ward round take? Clin Med (Lond). 2011; 11(1): 20-2. https://doi.org/10.7861/clinmedicine.11-1 $-20$

[35] Seeking consent: working with older people [Internet]. Department of Health. Cited 2017 Aug 23]. Available from: http://www.health.wa.gov.au/mhareview/resources/d ocuments/UK_DoH_Consent_older.pdf

[36] Levinson W, Kao A, Kuby A, et al. Not all patients want to participate in decision making. A national study of public preferences. J Gen Intern Med. 2005; 20(6): 531-5. PMid: 15987329. https://doi.org/10.1111/j.1525-1497.2005.04101.x

[37] Omvårdnad vid hjärtinfarkt [Nursing care in patients with myocardial infarction]. Vårdgivarwebb för Region Östergötland. Cited 2017 Aug 8. Available from: 
http://vardgivarwebb.regionostergotland.se/Star tsida/PM-medicinska-o-vardadm/PM-dokument/Kardiolo giska-kliniken-ViN/Omvardnad-vid-hjartinfarkt/

[38] Omvårdnadsåtgärder vid hjärtinfarkt observation [Nursing care in patients observed for chest pain]. Vårdgivarwebb för Region Östergötland. Cited 2017 Aug 8. Available from: http://vardgivarwebb.regionostergotland.se/Starts ida/PM-medicinska-o-vardadm/PM-dokument/Kardiologi ska-kliniken-ViN/Omvardnadsatgarder-vid-hjartinfa rkt-observation/
[39] Omvårdnad vid hjärtsvikt [Nursing care of patients with heart failure]. Vårdgivarwebb för Region Östergötland. Cited 2017 Aug 8. Available from: http://vardgivarwebb.regionostergotland.s e/Startsida/PM-medicinska-o-vardadm/PM-dokument/Ka rdiologiska-kliniken-ViN/Omvardnad-vid-hjartsvikt/

[40] Salam A, Siraj HH, Mohamad N, et al. Bedside teaching in undergraduate medical education: issues, strategies, and new models for better preparation of new generation doctors. Iran J Med Sci. 2011; 36(1): 1-6. PMid: 23365470. 